\title{
1. Why Microfranchising is needed now: introduction and book overview
}

\author{
Jason S. Fairbourne
}

There is no doubt that the free market, as now organized, does not provide solutions to all social ills. It provides neither economic opportunities nor access to health and education for the poor and elderly. ${ }^{1}$

We live in a unique period of time in which people living in developed nations, such as the United States, enjoy technological advancements that have surpassed previous generations' wildest imaginations and are experiencing a standard of living that was unfathomable half a century ago. Simultaneously, many more are suffering from the tribulations of poverty.

Our world continues to develop technologically at an exponential rate. When learning of new technological innovations, my wife reflects on Penny from the late 1980s cartoon Inspector Gadget. In this futuristic cartoon Penny had a notebook that she would use to contact Inspector Gadget and access information from a vast database. Two decades later we call it a Blackberry. I personally own an iPod that has 60 GB of memory; plays movies, songs, audio books, and games; and is smaller than the basic calculator I possessed in high school. This amount of memory is remarkable considering I recently bought my parents a new computer, which replaced their ten-year-old IBM that had less than 1 GB of memory.

Other advancements, such as the Internet, have allowed us to communicate with people around the world as if they were in the cubicle next door. The Internet has also provided anyone who can use a keyboard access to unlimited information, just like Penny. All of these advancements, plus many others, have led to the flattening of our world ${ }^{2}$ and allowed the most fortunate to live copious lifestyles.

Regardless of our ingenuity and unsurpassed standard of living, when considering international income levels and poverty, the world is anything but flat. Nearly four billion people still live in poverty, resulting in the deaths of 30000 children each day. In 2003, 10.6 million of these children died before they reached the age of five. 
Numerous similar statistics exist. However, I have found it is hard to explain, and for some to truly understand, the intricacies of poverty solely through mind-boggling statistics. I say this not because I believe that we humans are a callous bunch, or cannot comprehend figures, but simply because I believe that we are emotional beings. We have heard the statistics year after year, yet we allow continents such as Africa to continue to grow poorer.

A girl from my community was kidnapped a few years ago; they found her miraculously over a year later. In the interim, thousands scoured the local mountains searching for her and the story was broadcast around the world, millions knew that she was missing, and had followed the story. Roughly a year after the reunion with the girl and her family, I was living in London and mentioned to a colleague that I was from Utah. He said, "Oh, I know about Utah. That is where Elizabeth Smart was kidnapped. She was on the news every night in Wales." Joseph Stalin and his infamous comment that "a million deaths is a statistic, one death is a tragedy" immediately came to mind. I thought to myself, the true tragedy that this person and millions of others do not see on their televisions is the 30000 children who die each day from starvation, malnutrition, malaria, TB, diarrhea, and many other preventable diseases. They are no different from Elizabeth Smart, except for the fact that many of those deaths could have been prevented for a few dollars.

However, statistics do impact some of us. Scott Hillstrom read the previous statistic and woke up one day conjuring up the image of 30000 dead children a day being piled on his front yard. The image was mortifying, and he decided to do something about it. He now has 64 health shops in Kenya providing essential medicines to poor people who previously had no access to medicines. He made a difference. Scott created a business system that delivered health care services to the rural areas of Kenya. He systematized the operation and replicated it 64 times.

The replication of business systems at the grassroots micro level with the intent to alleviate poverty is what we have termed microfranchising. It mirrors franchising except on a smaller scale, with intents to benefit those at the bottom of the pyramid rather than merely elevate the wealthy. Scott Hillstrom's HealthStores are considered microfranchises; they are systematized businesses that are replicated. The underlying intent of a microfranchise is to alleviate poverty through the creation and provision of sound, proven businesses that will in turn increase the earning potential of the microfranchisee. Microfranchises are independently owned and operated; thus, they create income for the individual owner and the owner's employees, while simultaneously providing needed goods and services at an affordable price. 
Microfranchising is needed now more than ever. Poverty is ubiquitous throughout the developing world with little signs of diminishing. Market globalization is spreading across the world but leaving many behind while income inequality continues to increase. There have been many attempts to alleviate poverty over the years; some tools have experienced more success than others. More recently there has been a movement for market-based theories of development, particularly Stuart Hart's ${ }^{3}$ and C.K. Prahalad's ${ }^{4}$ work concerning the base of the pyramid (BOP). This introduction provides an overview of poverty and why microfranchising is needed, briefly describes some of the major methods previously deployed to assist people in need, and highlights the following chapters of this book.

\section{POVERTY}

Currently more than eight million people die around the world each year because they are too poor to stay alive. ${ }^{5}$

Both portraying and understanding poverty with its associated destructive implications is indeed a challenge. I have spent a fair amount of time in developing countries, I have lived in mud houses, and I still find defining or describing poverty difficult. The most effective method that $I$ have found is to share personal accounts of this appalling scourge, appalling because absolute poverty can be eradicated.

My first international experience took me to East Asia where I found myself assisting young homeless children in Katmandu; my heart went out to them. But not until a few years later, while living in a rural village in Kenya, did I actually begin to understand what poverty truly is. I was retuning to my boma (home) when a neighbor approached me with a lost, troubled look in her eyes. She rushed me to her boma where I was handed a small child who lay limp, bending backward over my arms. The child was shaking violently, her eyes were rolled back in the head, and a white substance permeated the mouth. My medical knowledge was limited to my trusty bible Where There Is No Doctor (Werner, Thuman and Maxwell, 2006), a book that details symptoms and treatments for primary sicknesses that affect those in developing nations. However, to my credit, I had seen many cases of malaria while in Kenya and spotted it immediately. My first question was how long had the child been in her current state. The answer was a shocking 18 hours. Stunned, I asked the woman what she had done over the last 18 hours to assist her child; I was hoping she would say she visited the clinic, a 45-minute walk down the street. 
Unfortunately, she replied that her husband had been searching for the bush doctor to cast the demons out all day and had not returned. I did not want to go against the wishes of her husband, but I knew the child was in the late stages of malaria, so I asked the woman if she would like to visit a medical clinic. She responded yes and I put the woman and child on the back of my motorcycle and was at the clinic in less than five minutes. The clinic was closed, but we found the doctor who lived adjacent to the clinic. She diagnosed the child with malaria and further warned the child would not live long without immediate treatment. For a ten-cent (subsidized) treatment the child was walking three days later.

For the few minutes that I held the child, I empathized with her. I felt the child's pains, struggles, and confusion. As if the young girl was telepathing the question "why?" I asked myself the same question. The face of the young innocent child is still vivid in my mind and I still ask "why?" The child had done nothing to deserve her predicament, except be born into a poor family in Sub-Saharan Africa.

The concept of poverty has many faces, can be approached in many ways, and is difficult to measure. In order to avoid the poverty debates concerning various concepts, I will use the World Bank's definition, which includes many aspects of poverty:

Poverty is hunger . . . lack of shelter . . . being sick and not being able to see a doctor. Poverty is not being able to go to school and not knowing how to read. Poverty is not having a job, is fear for the future, living one day at a time. Poverty is losing a child to illness brought about by unclean water. Poverty is powerlessness, lack of representation and freedom.

Poverty has many faces, changing from place to place and across time, and has been described in many ways. Most often, poverty is a situation people want to escape. $^{6}$

The developing world is plagued with chronic poverty, which is perpetuated through wars, AIDS, natural cataclysms, corruption, and many other complex variables. Africa and South Asia are the most poverty-stricken regions in the world, with the "lowest levels of per capita income."7 A 2004 article in The Economist highlighted the frailty of the developing world, paying specific attention to the precariousness of Africa. Half of Africa's population lives on less than 65 cents a day; furthermore, Africa, as a whole, is the only continent to grow poorer in the last 25 years. ${ }^{8}$

Poverty is a vicious cycle that spirals out of control as each detrimental variable builds upon a previous one. Education, lack of hope, government, globalization, trade laws, population growth, lack of access to credit, natural disasters, lack of employment, war, disease, and many other variables combine to hold people in poverty. These variables are so inter-related 
that one does not supersede the other. For example, an impoverished family is struggling to survive by growing their own food and selling whatever they can to pay for school fees. Life is not easy, but they are surviving and they have hope for a better future for their educated children. Slowly the rains become fewer and fewer until it is official that their region is suffering from a drought. At first they have no surplus to sell, so their children are pulled from school. Then they are unable to produce enough food to survive, so they pack up and move to an urban center to find employment. Ultimately they lose hope for their children's future, they have abandoned their land, and years later, just as they are getting back on their feet, a coup forms to overthrow the government, starting a civil war. There are many examples and relationships among these variables, but the important thing to remember is they are inter-related.

One of the primary problems with development theories is everyone seems to have the solution to end poverty. Unfortunately, there is no silver bullet to ending poverty, there are merely tools that, if used properly and in conjunction with each other, can alleviate and end poverty.

\section{MARKET GLOBALIZATION}

There is no doubt poverty is present throughout the world, most of all in the developing world. With the onset of market globalization, people living in poverty have little choice but to turn to the market and create businesses to survive. They operate microenterprises in the informal economy, and they are innovative and persistent. But as much as we should admire their resolution to work hard and improve their lives, they remain very poor. Simply put, market economies as they are currently structured do not work for the poor. People operating within informal economies manage to eke out a hand-to-mouth subsistence living but do not have the know-how, skills, or capital needed to be successful business owners. In essence, they are forced entrepreneurs.

Amartya $\operatorname{Sen}^{9}$ argues that increasing a person's capabilities is how development should be addressed; the right to work and earn a sufficient wage is a prudent method to the actualization of one's capabilities. Thus, according to Sen, the market is an important tool for increasing the standard of living of millions of people around the world. He is right that markets have indeed been successful, primarily in Asian countries and particularly in China; however, I must note that China's market is managed by a strong government. In other continents, such as Africa, weak states cannot govern the market effectively, and the poor suffer as a result. Even in China, recent studies show that income inequality is increasing rapidly. ${ }^{10}$ 
Globalization as defined by Joseph Stiglitz ${ }^{11}$ is:

The closer integration of the countries and peoples of the world which has been brought about by the enormous reduction in the cost of transportation and communication, the breaking down of artificial barriers to the flows of goods and services, capital, knowledge, and (to a lesser extent) people across borders.

Market capitalism is currently the prevailing ideology and development strategy and has been since the Bretton Woods conference in 1944, where the International Monetary Fund (IMF) and the International Bank for Reconstruction and Development (IBRD, which is commonly known as the World Bank) were formed. Market globalization is currently a buzz topic with advocates at each end of the debate fervently arguing their perspectives. The reality is that market globalization has had both successes and failures. One benefit of the general adoption of market ideology is it has provided a space for people to operate and earn a living. However, most do so informally, using the market merely as a survival mechanism. Additionally, one primary failure of the market globalization is that the income gap between the poor and the wealthy continues to increase. Thus, the poor are not the primary beneficiaries of market globalization as it is currently structured.

A few interesting statistics ${ }^{12}$ show that:

1. Twenty percent of the population in developed nations consume 86 percent of the world's goods.

2. In 1960, 20 percent of the world's people in the richest countries had 30 times the income of the poorest 20 percent - in 1997, 74 times as much.

3. The combined wealth of the world's 200 richest people hit $\$ 1$ trillion in 1999; the combined income of the 582 million people living in the 43 least developed countries is $\$ 146$ billion.

4. An analysis of long-term trends shows the distance between the richest and poorest countries was roughly:

-3 to 1 in 1820 ;

-11 to 1 in 1913;

-35 to 1 in 1950 ;

-44 to 1 in 1973 ;

-72 to 1 in 1992.

Figure 1.1 shows the distribution of world GDP for 1989.

Furthermore, the prevailing theory is that the cost of goods and services decrease as market globalization spreads, trade barriers are lessened and access to goods and services increases. This is indeed what we experience in developing nations. However, developing countries have not benefited as we have. Goods and services often cost more to the poor than they do to 


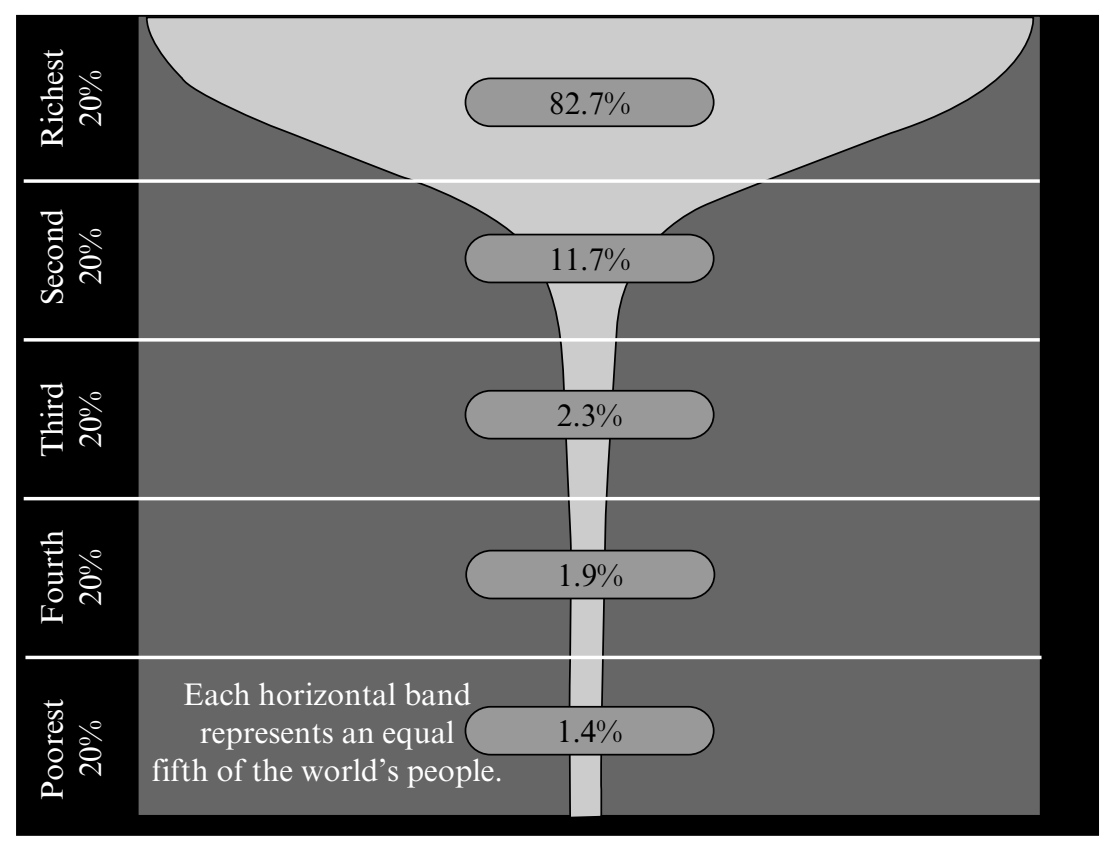

Source: United Nations Development Programme 1992, Human Development Report 1992 (New York: Oxford University Press for the United Nations Development Programme). ${ }^{13}$

\section{Figure 1.1 Distribution of world GDP, 1989 (percentage of total, with quintiles of population ranked by income)}

wealthy consumers in developed nations and more than they cost middleclass citizens in their own countries. A report to the Secretary General of the United Nations ${ }^{14}$ illustrates this point: "In Mumbai, slum-dwellers in Dharavi pay 1.2 times more for rice, 10 times more for medicines, and 3.5 times more for water than do middle class people living at the other end of the city on Bhulabhai Road." All in all markets alone are not the panacea to eliminating poverty. However, they are part of the solution.

The market has successes as well. Currently, the market, primarily the informal market, provides employment opportunities and provides goods and services that weak markets cannot. For example, in developing countries, 63 percent of health care expenditures are in the private sector, as opposed to 33 percent spent in developed countries. ${ }^{15}$ The downside is, as previously mentioned, the products come at a high price.

Many tools have been implemented to assist those operating within informal markets: from business development services (BDS) intended to assist existing microenterprises grow and develop their business to the 
tool of microfinance, which scales easily and provides access to capital to grow or establish a new business. The microfinance tool has arguably made the largest impact on poor people operating in market economies. Furthermore, there is a great potential for partnership between microfranchising and microfinance. In fact, we are already seeing partnerships being forged. Here are a few examples. BRAC, a large microfinance institution (MFI) in Bangladesh, has village health workers, called Shastho Shebikas, who have been trained to treat basic health ailments, record health information, and refer patients to health centers, in addition to selling essential health commodities to earn a profit. BRAC has replicated these health shops across Bangladesh and is currently partnering with the Scojo Foundation (see the case study in Part II) to add eyeglasses to its product offering. Grameen has been operating a village phone program where their borrowers sell phone time for years. SKS Microfinance is launching a franchise division and FINCA is in discussions with Honey Care Africa. The MicroFranchise Development Initiative at Brigham Young University is partnering with Freedom from Hunger to create a microfranchise that delivers health services to the poor in Ghana while providing a business for microcredit borrowers. These developing partnerships are not surprising, and I expect the trend to continue. Additional economic development tools will be discussed in greater depth by Warner Woodworth in Chapter 4 .

C.K. Prahalad and Stuart Hart have been leading the way with the BOP movement, demonstrating that businesses can alleviate poverty through profits. They argue there is a large untapped market at the base of the pyramid, and if companies will restructure their delivery systems to provide goods and services at an affordable price, they can serve the poor while earning profits. The underlying theory is to sell products to billions of people at smaller margins instead of selling to millions of people at higher margins. The result of this action is a win-win situation for the poor and for investors. I believe it is indeed a good idea. However, the question remains: how do large companies restructure themselves to profit off of volume and penetrate a market with little to no infrastructure? This book proposes a new tool to assist the forced entrepreneur to create employment and to provide a method for MNCs to get their goods and services to the market, all in a sustainable manner through a concept called microfranchising.

\section{MICROFRANCHISING: THE NEW TOOL}

Besides the fact that the average US franchise costs roughly $\$ 250000^{15}$ and microfranchises range from $\$ 25$ to $25000,{ }^{17}$ the "micro" in microfranchising stands for more than mini or small. "Micro" is essential to microfranchising 
and in this sense has a social connotation that refers to grassroots bottom-up initiatives, poverty alleviation, benevolence, base of the pyramid, and the like. The term micro has been built up by the success of microfinance. Microfinance is, in its simplest form, the provision of capital to a person who lacks access to a formal financial institution. Microfinance has been extremely successful in reaching over 200 million people, while for the most part being economically sustainable. With all things considered, "micro" also represents sustainability. Thus, microfranchising can be thought of as poverty alleviating, social, grassroots, BOP, benevolent, and barefoot franchising.

The franchise in microfranchise represents replication to scale. This involves systematizing an operation, paying close attention to each and every aspect of a business until it is a turn-key operation, then replicating it to scale. Franchising embodies the concept of granting the right, privilege, or access to a proven business system. There is much to be learned from traditional franchises, which can be applied to microfranchising.

The marriage of the two terms makes up microfranchising, which is indeed very different from both microfinance and from franchising. For example, in traditional franchising, the purpose for establishing a franchise is to grow one's business quickly in order to increase profits. In microfranchising, the focus is more on the microfranchisee and how he/she benefits from buying into a proven systematized business. A microfranchise is established to assist the poor in creating a sustainable income through owning and operating their own business. The reduction of risk, provision of specific training, ongoing mentoring, and reduction of creative burden are all benefits to the microfranchisee. Microfranchises above all are established as a poverty-alleviation tool:

Microfranchising addresses three core problems that prevent people from becoming economically self-reliant. (1) The lack of skills needed to grow a successful business. (2) The lack of jobs in developing countries. (3) The lack of goods and services available to the poor.

Microfranchising provides a solution to these core problems by first, providing those who do not possess an entrepreneurial skill set with a business blueprint that, if followed, will lead to greater individual economic success. Thus, it is not necessary to have an entrepreneurial spirit in order to be a successful microfranchisee. In fact, a true entrepreneur would not be a good candidate as a microfranchisee. Second, microfranchises are often larger than traditional microenterprises; thus, creating jobs for those who do not have managerial skills and would be better suited as an employee or technician. Third, microfranchising provides multinational corporations (MNCs) with an effective method of delivery for their goods and services to the BOP at an equitable price. ${ }^{18}$

There are three key underlying financial structures that underpin the various business models (microfranchise business models will be discussed 
in Chapter 7). The three key underlying financial structures are as follows: social microfranchising, sustainable microfranchising, and for-profit microfranchising. A microfranchise may begin operations in any one of these models and shift to another and ultimately end up as an amalgamation of multiple models.

\section{Social Microfranchising}

The objective of social microfranchising is first and foremost to provide goods and services at an affordable price and secondly to create jobs at the BOP. Social microfranchising operates off of a financial model that is not focused on sustainability. Therefore, a social microfranchise does not mind subsidizing product costs in order to reach its objective. One obvious drawback of the model is that a continuous flow of funds into the project is needed. The benefit is that it is easier for the microfranchisee to earn higher income when the products cost him/her less. Also, the lower costs are passed on to the consumer. This model is commonly used by pharmacies in developing countries.

\section{Sustainable Microfranchising}

Sustainable microfranchising approaches the business model from an objective to create profit for the microfranchisee and enough surplus profit to sustain the microfranchisor. Any additional profit is used to either create more franchises or to assist the existing microfranchisees in increasing their profits through initiatives such as additional training and marketing. This model seeks a triple bottom line, which is: (1) creating profit for the microfranchisee; (2) financial sustainability; and (3) the provision of goods and services at an equitable cost.

\section{For-profit Microfranchising}

For-profit microfranchising is very similar to sustainable franchising with one added variable, which is to create enough profit for the microfranchisor to return profit to investors. The obvious downside is the potential for exploitation when a franchise system is not fully developed and is struggling financially. This model requires much higher start-up capital in order to scale quickly and become profitable enough to repay investors. Even within the sustainable microfranchise model, sustainability may not occur until the franchise system has grown to a sustainable point; that is to say, a microfranchise in any model may not be sustainable until it has a certain number of franchisees operating franchises that pay royalties. Thus, the 
start-up capital must be significant enough to launch enough microfranchises to generate profit for investors. This model works best with multinational corporations and the like (see the Vodacom case study in Part II of this book). People and organizations that pursue this model but lack the financial and technical capacity to see it through, run the risk of losing sight of the social aspect and placing an undue amount of emphasis on repaying investors. This is my primary concern with this model.

All three models contain "micro" and thus have a social objective. However, it is obvious that varying degrees of benevolent motives exist. Ultimately there is a fine balance between meeting financial objectives to reach sustainability and assisting the poor simultaneously. I believe this will be the ultimate challenge for microfranchisors as microfranchises continue to be launched. Various microfranchise business structures are emerging, with some adopting NGO status, others private, and some an amalgamation of the two, as is seen with Honey Care Africa (see Chapter 8).

Markets are indeed extremely important to the poor, just as they are to those who have benefited from them in developed countries. Markets are where people earn a living and survive; thus, markets must be made to work for the poor. Markets can be very harmful to the poor if they are exploitative. I believe microfranchising offers a path to increase success for those operating in developing and often informal markets without exploiting those at the bottom. Microfranchising is needed now more than ever; in fact, it may not have worked 20 years ago. Microfinance has paved the way and established a strong platform for new microeconomic development tools including microfranchising. However, it must be noted that markets are not the solution; they are merely part of the solution to the poverty conundrum. Governments are equally important; strong governments are imperative to govern markets. Microfranchising is a grassroots, bottom-up approach to increasing the success of people operating within emerging or developing markets. With market globalization and income inequality increasing, the deployment of microfranchising as a method of making markets work for the poor has great potential to create wealth at the base of the pyramid, allowing people to reach a state of economic self-reliance.

\section{BOOK OVERVIEW}

The following chapters were specifically written for this book; thus, there is more continuity and flow to this book than a typical edited publication that compiles essays and articles from various sources. The editors have selected key authoritative individuals to author chapters related to their field of 
expertise. The book is broken into three parts. Part I deals with theories of microfranchising and its potential to be a valuable poverty alleviation tool. Part II focuses on microfranchise business models, provides four case studies and discusses how to finance microfranchises, followed by the conclusion in Part III.

\section{Part I: Microfranchise Theory}

In Chapter 2, Stephen W. Gibson addresses the core microfranchising issues. Microfranchising is a new burgeoning poverty alleviation tool that is gaining much traction. However, considering the novelty of the concept, Chapter 2 is crucial in establishing a firm foundation concerning what microfranchising is and how it works.

Michael Henriques and Matthias Herr discuss the relationship between microfranchising and the informal sector in Chapter 3. They highlight various concepts surrounding the informal economy and how microfranchising can be a valuable tool not only to create employment but also to create sustainable businesses that move people out of informality and into formal institutions with the associated rights and privileges.

Microfranchising is a new tool, but there are many other tools that have been developed to assist those in the informal economy and lift people out of poverty. Warner Woodworth, in Chapter 4, addresses the current economic development tools and their corresponding advantages and disadvantages.

John Hatch, author of Chapter 5, outlines the benefits of microfranchising to the microcredit industry and how microcredit can assist microfranchising. He discusses the strengths and deficiencies of both microfinance and microfranchising; he concludes that the combination is more effective than either initiative as a stand-alone development tool.

Eliot Jamison and Molly Hoyt, tackle the issue of MNCs, the base of the pyramid, and microfranchising in Chapter 6 . They begin the journey with corporate interest in emerging markets, MNCs' social responsibility, financial opportunity, and the need for innovation. This discussion leads Jamison and Hoyt into Hart and Prahalad's BOP literature and identifies cases of MNCs that have taken on the challenge of reaching the BOP. Jamison and Hoyt expound on the following three concepts: microfranchising as a distribution channel, microfranchises as a supply base, and microfranchising as an enterprise development strategy.

\section{Part II: Microfranchising in Practice}

Part II highlights various microfranchising models and provides pertinent case studies designed to enhance readers' understanding of how 
microfranchising applies to development. Kirk Magleby identifies 15 microfranchise business models in Chapter 7; he provides brief examples that exist in both developed and developing countries. The complexity of the models varies greatly - from a business-in-a-box to a business format microfranchise.

Chapters 8 through 11 examine four microfranchises in depth: Honey Care Africa, HealthStores, Vodacom, and Scojo. Honey Care Africa trains people to be beekeepers, provides them with the necessary equipment, and trains them to own and operate the microfranchise. HealthStores also operates in East Africa; it is located in Kenya and has a network of 64 health stores that provide essential medicines. Vodacom is an MNC that has utilized the microfranchising model to create impressive revenue. It has over 4000 microfranchises that sell phone services to people in rural villages in South Africa. Scojo is in operation in South America and in East Asia (India and Bangladesh) where it trains women to perform basic eye examinations and provides them with a backpack with eyeglasses, other complimentary products, and necessary tools to operate the business efficiently.

Naoko Felder-Kuzu, in Chapter 12, examines the idea that some microfinance funds, plus new funds, can be adjusted to support microfranchising. These microfranchise funds can be equally rewarding for both the franchise organizations and the franchisee. She addresses the key question as to how microfranchising can be funded.

Chapter 13 in Part III, written by W. Gibb Dyer, Jr, summarizes the opportun-ities associated with microfranchising, the barriers that will be faced, and future questions that need to be addressed.

\section{CONCLUSION}

This book is intended to highlight a new and innovative poverty-alleviation tool designed to create wealth at the base of the pyramid, and perhaps, spur some thought similar to Scott Hillstrom's that is followed by action. I propose we prove Stalin wrong; that the appalling poverty statistics do indeed have meaning, and that 30000 children dying each day means something. The true tragedy will be if absolute poverty does not become a statistic of the past. If people have access to income that leads to economic self-reliance, they will be able to provide the basic necessities for their children. They will be able to educate them, immunize them, feed them properly, and put an end to the horrifying poverty statistics.

Considering that markets have failures and do not always work for the poor and considering the proliferation of market globalization, microfranchises are needed now more than ever. Microfranchising is an essential tool 
that helps people be more successful working in market economies. Microfranchising has an important role to play in the poverty-alleviation movement; with the potential to have a lasting impact on the developing world. Microfranchising offers a sustainable method to deliver goods and services to the poor at an affordable price, through a social business format that increases income and reduces costs simultaneously; thus, creating wealth at the bottom of the pyramid.

\section{NOTES}

1. Yunus, Muhammad (1997), Banker to the Poor: Micro-lending and the Battle Against World Poverty, United States of America: Public Affairs.

2. Friedman, Thomas L. (2005), The World is Flat: A Brief History of the Twenty-first Century, United States of America: Farrar, Straus and Giroux.

3. Hart, Stuart L. (2005), Capitalism at the Crossroads: The Unlimited Business Opportunities in Solving the World's Most Difficult Problems, United States of America: Pearson Education, Inc.

4. Prahalad, C.K. (2005), Fortune at the Bottom of the Pyramid: Eradicating Poverty Through Profits, United States of America: Pearson Education, Inc.

5. Sachs, Jeffrey (2005), The End of Poverty: Economic Possibilities for Our Time, United States of America: The Penguin Press.

6. Understanding Poverty (2006), The World Bank Group, 11 June 2006, accessed at www.worldbank.org/WBSITE/EXTERNAL/TOPICS/EXTPOVERTY/0,,contentMDK :20153855 menuPK:373757 pagePK:148956 piPK:216618 theSitePK:336992,00.html.

7. Sen, Amartya (1999), Development as Freedom, United States of America: Anchor Books, and simultaneously in Canada: Random House of Canada Limited, p. 99.

8. The Economist (2004), "How to Make Africa Smile: A Survey of Sub-Saharan Africa", 17-23 January.

9. Sen, Amartya (1999), Development as Freedom, United States of America: Anchor Books, and simultaneously in Canada: Random House of Canada Limited.

10. The Economist (2006), "A Survey of China", 25-31 March.

11. Stiglitz, Joseph E. (2002), Globalization and Its Discontents, New York: W.W. Norton \& Company, Inc.

12. Shah, Anup, Poverty Facts and Stats, 3 April 2006. Global Issues That Affect Everyone, 11 June 2006, accessed at www.Globalissues.org/TradeRelated/Facts.asp.

13. Robert Hunter Wade (2001), 'The Rising Inequality of World Income Distribution', Finance and Development, 38:(4), December 2001.

14. Commision on the Private Sector and Development (2004), "Unleashing entrepreneurship: making business work for the poor", report to the Secretary General of the United Nations.

15. Ibid.

16. Quick Franchise, Franchising, Facts \& Statistics. 1999-2006. AZFranchises.com, 11 June 2006, accessed at www.azfranchises.com/franchisefacts.htm.

17. Fairbourne, Jason and Stephen W. Gibson (2005), Where There Are No Jobs, vol. 4.

18. Fairbourne, Jason (2006), "MicroFranchise development initiative: progressive thinking for creating economic self-reliance", Advances in Economic Self-reliance, forthcoming. 